\title{
Determination of thermotolerant coliforms present in coconut water produced and bottled in the Northeast of Brazil
}

\author{
Determinação da presença de coliformes termotolerantes em águas de coco \\ produzidas e envasadas no Nordeste brasileiro
}

\author{
Vandbergue Santos Pereira ${ }^{1 *}$, Johnatan Wellisson da Silva Mendes ${ }^{2}$, Lorena Alves Oliveira ${ }^{2}$, \\ Carlos Eberton Alves Mangueira², Edlânia Moraes Rodrigues², Fernando Gomes Figueredo² \\ 1 Universidade Federal do Ceará (UFC), Centro Especializado em Micologia Médica, Fortaleza/CE - Brazil \\ ${ }^{2}$ Centro Universitário Doutor Leão Sampaio (UniLeão), Departamento de Microbiologia, Juazeiro do Norte/CE - Brazil
}

\section{*Corresponding Author}

Vandbergue Santos Pereira, Universidade Federal do Ceará (UFC), Centro Especializado em Micologia Médica, Rua Coronel Nunes de Melo, 1380, Rodolfo Teófilo, CEP: 60430-275, Fortaleza/CE - Brazil, e-mail: vandbergue.vsp@gmail.com

Cite as: Determination of thermotolerant coliforms present in coconut water produced and bottled in the Northeast of Brazil. Braz. J. Food Technol., v. 21, e2016166, 2018.

Received: Nov. 16, 2016; Accepted: July 11, 2017

Abstract

Coconut water is considered to be a natural isotonic drink and its marketing is gradually increasing. The objective of the present study was to evaluate the microbiological quality of the coconut water produced and bottled in the Northeast of Brazil. Products form ten industries from different states in the Northeast of Brazil were analyzed. The most probable number (MPN) method was used to quantify the coliforms. Samples showing positive for coliforms were seeded on ChromAgar Orient plates and the bacteria identified from isolated colonies using the automated system Vitek 2 (BioMérieux), according to the manufacturer's instructions for the preparation of the inoculum, incubation, reading and interpretation. The samples showed thermotolerant coliform counts between $6.0 \times 10^{2}$ and $2.6 \times 10^{4} \mathrm{MPN} / 100 \mathrm{~mL}$. The presence of Klebsiella pneumoniae, Morganella morganii and Providencia alcalifaciens was observed. The implementation of preventive methods and monitoring of the water quality by the industries is required.

Keywords: Natural isotonic drink; MPN; Microbiological quality.

\section{Resumo}

A água de coco é considerada uma bebida natural isotônica e sua comercialização tem aumentado gradualmente. O objetivo do presente estudo foi avaliar a qualidade microbiológica da água de coco produzida e engarrafada na Região Nordeste do Brasil. Produtos de dez indústrias de diferentes estados foram analisados. Para a quantificação de coliformes, foi aplicada metodologia de Número Mais Provável (NMP). As amostras positivas para coliformes foram semeadas em placas de ChromAgar Orient e, a partir de colônias isoladas, foi realizada a identificação bacteriana, utilizando-se o sistema automatizado Vitek 2 (BioMérieux), de acordo com as instruções do fabricante para a preparação do inóculo, a incubação, a leitura e a interpretação. As amostras apresentaram contagem de coliformes termotolerantes entre $6,0 \times 10^{2}$ e 2,6×104 NMP/100 mL. Foi observada a presença de Klebsiella pneumoniae, Morganella morganii e Providencia alcalifaciens. A implementação de métodos de prevenção e monitoramento da qualidade da água pelas indústrias é necessária.

Palavras-chave: Bebida natural isotônica; NMP; Qualidade microbiológica.

\section{Introduction}

In Brazil, the coconut crop is used almost exclusively for in nature human consumption (coconut water and culinary use), a practice that involves issues related to transportation, storage and perishability of the product (MARTINS; JESUS JÚNIOR, 2011). Brazil currently ranks fourth in the ranking of the largest coconut producers, with an estimated production of 
2.8 million tons in an area of 287,000 hectares. The Brazilian Northeast region accounts for about $70 \%$ of this production (JESUS JÚNIOR et al., 2013).

The continued growth of coconut water consumption has encouraged the modernization and implementation of new production, distribution and marketing methods, which seek to ensure not only the continued use of the product on the market, but also the extension of product quality, since several studies have elucidated the risks and propensity to contamination of the fresh fruit market due to the precariousness of food handling (FORTUNA; FORTUNA, 2008).

In Brazil, the agency responsible for the regulation of the coconut water production is the Ministry of Agriculture, Livestock and Food Supply, which relates the required microbiological characteristics of coconut water submitted to industrial processes and destined for human use as a beverage in norm $n^{\circ} 27$ of July $22^{\text {nd }}, 2009$. It advocates the absence of Salmonella spp. and the presence of coliforms should not exceed $10^{2}$ cells/100 mL (BRASIL, 2009).

Bacteria belonging to the faecal coliform group have a great impact as indicators of faecal contamination. These bacteria belong predominantly to the gastrointestinal tract, with the fermentation of lactose to acid and gas production at temperatures between 44.5 to $45.5^{\circ} \mathrm{C}$ as their main metabolic characteristic. Escherichia, Enterobacter and Klebsiella are the major genera in this group (RECHE et al., 2010).

The microbiological analysis of coconut water samples is crucial to public health, since the hygienic and sanitary characteristics during the processing of these products are directly related to consumer health. Thus, the aim of the present study was to evaluate the microbiological quality of coconut water produced and bottled in the Northeast of Brazil.

\section{Material and methods}

\subsection{Sampling}

Bottled coconut water samples from ten manufacturers distributed throughout the Northeast of Brazil, in the states of Alagoas (AL), Ceará (CE), Paraíba (PB), Pernambuco (PE) and Rio Grande do Norte (RN), were used in this study. Two batches were obtained from each manufacturer and three samples were examined per batch, giving a total of 60 samples, including shelf-stable and fresh refrigerated product samples, as described in Table 1. All the tests were carried out in the Microbiology Laboratory and other support laboratories at the Leão Sampaio School - Health Campus in Juazeiro do Norte-CE.

\subsection{Determination of thermotolerant coliforms}

The multiple-tube technique (APHA, 2015; SILVA et al., 2010b) was used to determine the coliforms. For this analysis, $100 \mathrm{~mL}$ of each sample was seeded into tubes containing lactose broth and incubated at $37^{\circ} \mathrm{C}$ for $24 \mathrm{~h}$, as well as into EC broth with incubation at $44-45^{\circ} \mathrm{C}$ for $24 \mathrm{~h}$. The most probable number (MPN) method was used for quantification (SILVA et al., 2010b).

\subsection{Isolation and identification of the microorganisms found}

Samples from lactose broth tubes showing growth were seeded onto CHROMagar Orientation medium (BD Diagnostics, Franklin Lakes, NJ), re-isolated when necessary, and then tested for Gram coloration performed for their classification as gram positive or gram negative bacteria. The bacteria were identified from isolated colonies using the automated system Vitek 2 (BioMérieux) according to the manufacturer's instructions for the preparation of the inoculum, incubation, reading and interpretation.

\section{Results}

Table 1 shows the results for the microbiological analysis of the thermotolerant coliforms present in the coconut water obtained from the different manufacturers, produced and bottled in the Northeast of Brazil. Of the ten industries analyzed, six did not conform to the microbiological standards determined by the legislation.

Table 2 shows the results of the biochemical identification of the contaminating bacteria present in the coconut water samples as determined by the Vitek 2 system. The presence of three different bacterial species was observed: Klebsiella pneumoniae; Providencia alcalifaciens and Morganella morganii.

\section{Discussion}

The results observed for the presence of thermotolerant coliforms showed samples which did not conform to norm $\mathrm{n}^{\circ} 27$ of the Ministry of Agriculture, Livestock and Food

Table 1. Microbiological analysis of faecal coliforms present in coconut water from the Northeast of Brazil.

\begin{tabular}{|c|c|c|c|c|}
\hline Samples & State & $\begin{array}{c}1^{\text {st }} \text { Batch } \\
\text { (MPN/100 mL) }\end{array}$ & $\begin{array}{c}2^{\text {nd }} \text { Batch } \\
\text { (MPN/100 mL) }\end{array}$ & Classification $^{\circ}$ \\
\hline Industry $A^{a}$ & CE & $2.4 \times 10^{4}$ & $6 \times 10^{2}$ & Improper \\
\hline Industry $\mathrm{B}^{\mathrm{a}}$ & CE & $1.4 \times 10^{4}$ & $1.4 \times 10^{4}$ & Improper \\
\hline Industry $C^{a}$ & PE & $1.7 \times 10^{3}$ & $3.3 \times 10^{3}$ & Improper \\
\hline Industry $D^{a}$ & PE & $3.2 \times 10^{3}$ & $2.6 \times 10^{4}$ & Improper \\
\hline Industry $E^{a}$ & PB & $1.7 \times 10^{3}$ & $3.3 \times 10^{3}$ & Improper \\
\hline Industry $F^{a}$ & $\mathrm{RN}$ & $1.4 \times 10^{3}$ & $1.4 \times 10^{3}$ & Improper \\
\hline Industry $\mathrm{G}^{\mathrm{b}}$ & $\mathrm{RN}$ & $<10^{2}$ & $<10^{2}$ & Proper \\
\hline Industry $\mathrm{H}^{\mathrm{a}}$ & $A L$ & $<10^{2}$ & $<10^{2}$ & Proper \\
\hline Industry | ${ }^{\mathrm{b}}$ & $\mathrm{AL}$ & $<10^{2}$ & $<10^{2}$ & Proper \\
\hline Industry Ja & PB & $<10^{2}$ & $<10^{2}$ & Proper \\
\hline
\end{tabular}

Results expressed as the arithmetic mean of quantifications carried out in triplicate; a Shelf-stable product; ' ${ }^{2}$ Fresh refrigerated product; c Limit permitted by the legislation: $10^{2}$ MPN/100 mL. 
Table 2. Biochemical identification of the bacterial contaminants in coconut water from the Northeast of Brazil by the VITEK2 system.

\begin{tabular}{cccc}
\hline Samples & State & $\mathbf{1}^{\text {st }}$ Batch & $\mathbf{2}^{\text {nd }}$ Batch \\
\hline Industry A & CE & Klebsiella pneumoniae & Klebsiella pneumoniae \\
Industry B & CE & Providencia alcalifaciens & Morganella morganii \\
Industry C & PE & Klebsiella pneumoniae & Klebsiella pneumoniae \\
Industry D & PE & Morganella morganii & Morganella morganii \\
Industry E & PB & Klebsiella pneumoniae & Klebsiella pneumoniae \\
Industry F & RN & Morganella morganii & Morganella morganii \\
\hline
\end{tabular}

Supply (BRASIL, 2009) which regulates the microbiological characteristics of the food and demands the absence of Salmonella sp. and the presence of thermotolerant coliforms below the limit of $10^{2}$ cells $/ \mathrm{mL}$ for coconut water. Lima et al. (2015), when analysing industrialized coconut water produced in the states of Ceará and Paraíba, found similar results for the presence of species of this group. The presence of these organisms indicates contact with faecal contaminants during the filling process, which may be associated with a deficit in the control of manipulation.

Another highlight of this study was the absence of bacteria reported as potential contaminants of water and food in the microbiological analysis, such as Escherichia coli and Salmonella sp. In a study of the microbiological quality of coconut water marketed in Currais Novos/RN, Silva et al. (2010a) obtained similar results regarding the absence of those microorganisms, which may be explained by the reduction in temperature during both the production $\left(24^{\circ} \mathrm{C}\right)$ and storage processes $\left(5^{\circ} \mathrm{C}\right)$.

The presence of Klebsiella pneumoniae was observed amongst the thermotolerant coliforms, which is associated with gastrointestinal disorders. A study by Santos et al. (2005) showed the presence of K. pneumoniae in $80 \%$ of the food samples prepared by hand manipulation. These bacteria were found mainly in samples containing fresh fruit as a major element of their compositions. This species is indicated as a cause of meningitis, endocarditis and pneumonia, amongst other diseases of the respiratory tract (FORSYTHE et al., 2015).

Moreover a significant presence of Morganella morganii and Providencia alcalifaciens was detected, organisms occasionally found in food contamination or on inanimate surfaces where food manipulation occurs. They are clinically associated with gastroenteritis, $P$. alcalifaciens being more associated with intestinal infections in children. This species has been recovered from urine, stool, throat, perineum, axilla, blood, and wound specimens (O'HARA et al., 2000).

The contamination of coconut water commercialized in cups with thermo welded lids may be associated with poor storage conditions of the product or contamination of the raw material used in production, since all the processing of this type of packaging is carried out using specific industrial equipment which minimizes the chances of contamination during the production process.
Regarding the long-life packed samples analyzed, all the microbiological parameters conformed with the legislation. Long-life packages are aseptic, ideal for the packaging of food due to their structural composition, allowing for better food preservation (RAI; SHARMA, 2014).

\section{Conclusions}

Of the samples obtained from the ten industries analyzed, half did not conform to the microbiological standards established by the legislation with respect to the presence of faecal coliforms amongst other potentially pathogenic microorganisms, which makes the product improper for consumption. It is worth noting the absence of Salmonella spp., Escherichia coli, and Staphylococcus spp. in all the samples.

The results suggest that contamination may have occurred due to the use of contaminated raw material and inadequate storage times and temperatures, important factors in maintaining the microbiological quality of any food. It was noticed that long-life packaging had the greatest potential for conservation of the microbiological characteristics of coconut water.

It is recommended that the public entities enforce the use of preventive actions by the industries to stimulate better practices in production, as well as the adoption of control methods aimed at excellence in product quality, with a view to offering products that do not offer any risk to public health.

\section{Acknowledgements}

This work was made possible due to financial and technical support from University Center Doctor Leão Sampaio (UniLeão), Ceará, Brazil.

\section{References}

AMERICAN PUBLIC HEALTH ASSOCIATION - APHA. Compendium of methods for the microbiological examination of foods. Washinton: APHA, 2015.

BRASIL. Ministério da Agricultura, Pecuária e Abastecimento. Normativa $n^{\circ} 27$, de 22 de julho de 2009. Estabelece os procedimentos mínimos de controle higiênico-sanitário, padrões de identidade e características mínimas de qualidade gerais 
Determination of thermotolerant coliforms present in coconut water produced and bottled in the Northeast of Brazil Pereira, V. S. et al.

para a água de coco. Diário Oficial [da] República Federativa do Brasil, Brasília, DF, 2009.

FORSYTHE, S. J.; ABBOTT, S. L.; PITOUT, J. Klebsiella, Enterobacter, Citrobacter, Cronobacter, Serratia, Plesiomonas, and other Enterobacteriaceae. In: AMERICAN SOCIETY OF MICROBIOLOGY - ASM. Manual of clinical microbiology. 10th ed. Washington: ASM, 2015. p. 714-737. http://dx.doi. org/10.1128/9781555817381.ch38.

FORTUNA, D. B. S.; FORTUNA, J. L. Avaliação da qualidade microbiológica e higiênico sanitária da água de coco comercializada em carrinhos ambulantes nos logradouros do município de Teixeira de Freitas (BA). Revista Baiana Saúde Pública, v. 32 , p. 203-217, 2008.

JESUS JÚNIOR, L. A.; TOMMASI, A. C.; OLIVEIRA JÚNIOR, A. M.; RUSSO, S. L. Análise da produção de coco no Estado de Sergipe frente ao crescimento da cultura no Nordeste e no Brasil. Revista GEINTEC, v. 3, p. 400-408, 2013.

LIMA, S. A. J.; MACHADO, A. V.; CAVALCANTI, M. T.; LISBÔA, C. G. C. Análise sensorial da água de coco anão verde processada e comercializada no sertão paraibano e cearense. Revista Verde de Agroecologia e Desenvolvimento Sustentável, v. 10, n. 2 , p. 165-169, 2015. http://dx.doi.org/10.18378/rvads.v10i1.3466. MARTINS, C. A.; JESUS JÚNIOR, L. A. Evolução da produção de coco no Brasil e o comércio internacional: panorama 2010. Aracaju: Embrapa Tabuleiros Costeiros, 2011.
O'HARA, C. M.; BRENNER, F. W.; MILLER JUNIOR, M. Classification, identification, and clinical significance of Proteus, Providencia, and Morganella. Clinical Microbiology Reviews, v. 13, n. 4, p. 534-546, 2000. PMid:11023955. http://dx.doi.org/10.1128/ CMR.13.4.534-546.2000.

RAI, M. M.; SHARMA, T. R. Some recent developments in food packaging. Defence Science Journal, v. 16, n. 4A, p. 141-146, 2014.

RECHE, M. H. L. R.; PITTOL, M.; FIUZA, L. M. Bactérias e bioindicadores de qualidade de águas de ecossistemas orizícolas da Região Sul do Brasil. Oecologia Australis, v. 14, n. 2, p. 452-463, 2010. http://dx.doi.org/10.4257/oeco.2010.1402.08.

SANTOS, B. H.; COSTA, A. C.; SOUZA, E. L. D. SOUSA, C. P. D. Klebsiella pneumoniae como agente contaminante de dietas enterais artesanais. Higiene Alimentar, v. 19, n. 131, p. 58-60, 2005.

SILVA, J. L. A.; DANTAS, F. A. V.; SILVA, F. C. Qualidade microbiológica de águas de coco comercializadas no município de Currais Novos/RN. Holos, v. 34, n. 41, p. 34-41, 2010a. http:// dx.doi.org/10.15628/holos.2009.255.

SILVA, N.; JUNQUEIRA, V. C. A.; SILVEIRA, N. F. A.; TANIWAKI, M. H.; SANTOS, R. F. S.; GOMES, R. A. R. Manual de métodos de análise microbiológica de alimentos e água. 4. ed. São Paulo: Varela, 2010b. 